\title{
The Danube Question and the Making of Two River Commissions
}

The more modern supersedes the more ancient stipulation, $[\ldots]$

1815 must give way to 1856 .

Ambassador GEORge HAMilton SEYMour, 1857

A German View on the Freedom of the Danube

Christian Friedrich Wurm (1803-1859) was, in many ways, Urquhart's moderate, continental, German counterpart. He shared the Scotsman's anti-Russian bias and published several pieces in his Portfolio; he was equally interested in the entanglements of the Eastern Question and wrote in support of free trade. As a contributor to several German newspapers and magazines, Wurm often voiced his liberal opinions, and as professor of history at the Academic Gymnasium in the Hanseatic port-city of Hamburg he did extensive research on the close connection between economic systems and political regimes. But, first and foremost, he was a true patriot, eager to contribute to his fatherland's well-being. No wonder that Wurm praised the benefits of the Zollverein in shaping the German nation-state and took an active part in the revolution of $1848 .^{1}$

In the context of the Crimean War, Wurm followed closely the public debates on the status of the Danube, and in early 1855 published in Leipzig a brochure - Vier Briefe über die freie Donau-Schiffahrt. This collection of articles was a chronological presentation of Russia's Danubian intrusions during the first half of the nineteenth century. Several of his main arguments are similar

1 Adolf Wohlwill, 'Wurm, Christian Friedrich,' in: Allgemeine Deutsche Biographie, vol. 44 (Leipzig 1898), 326-332, digital version available at the address https://de.wikisource.org/w/ index.php?title=ADB:Wurm,_Christian_Friedrich\&oldid=2521888 (visited on 17 October 2018). 
to Urquhart's line of reasoning, though Wurm's approach displays more mildness and narrative subtlety. According to Wurm, Russia's policy at the Maritime Danube received a weak response from European cabinets, which had been lulled by the reassurances of the government in St Petersburg. Russia had never denied its obligation to keep the Danube open, but failed to effectively do so exactly when steamship navigation secured a direct and uninterrupted connection between the Levant and the German lands on the Upper Danube. As the allied powers' ultimatum addressed to Russia in December 1854 was to be followed by diplomatic negotiations in Vienna, Wurm advocated for a fair representation of German interests in relation to the new status of the Danube. ${ }^{2}$

Three years later, in 1858, Wurm published another collection of articles Fünf Briefe über die Freiheit der Flussschiffarht, und über die Donau-Akte vom 7 Nov. 1857. The brochure was a more detailed analysis of international law on the navigation of transboundary rivers, a hot issue following recent international developments. His articles touched on various facets, from the juridical innovations of the 1856 Paris Treaty to the sovereign rights of riparian states in accordance with the provisions of the 1815 Vienna Act. Wurm's narrative was meant as an expert opinion before a new ambassadorial conference, summoned to Paris in May 1858, which was to discuss - among other pending aspects of the Eastern Question - the future organisation of Danube navigation and hopefully harmonise the two opposing views on the status of international rivers. ${ }^{3}$

This chapter will analyse the international context between the publication of Wurm's two brochures, a period in which Europe's Great Powers found a (provisional) solution to the Danube Question during and in the aftermath of the Crimean War. The internationalisation and institutionalisation of Danube navigation through the stipulations of the 1856 Paris Treaty created exceptional juridical instruments that added to previous interpretations of the 1815 Vienna Treaty. Such legal instruments, it will be showed throughout this chapter and volume, contributed to broadening the institutional legacy of the European Commission of the Danube, taken as an example for further cooperation along international waterways.

2 Christian Friedrich Wurm, Vier Briefe über die freie Donau-Schiffahrt (Leipzig 1855).

3 Wurm, Fünf Briefe über die Freiheit der Flussschiffarht, und über die Donau-Akte vom 7 Nov. 1857 (Leipzig 1858); Parliamentary Papers, House of Commons and Command, Reports from Committees, Stade Tolls; Harbours of Refuge. Session 3 December 1857-2 August 1858, vol. 17 (London 1858), 1. 
Wurm's brochures are illustrative of the larger public interest in what had already become the Danube Question, a diplomatic dispute caused by the divergent views of European statesmen on the status of the river. At the outbreak of the Crimean War, one of the major political aims of the western powers was to remove Russia's exclusive control over the Maritime Danube. The intention was to establish a system of security and predictability for commercial exchanges along a strategic waterway that had a similar function, at a regional level, to that enjoyed by the Straits of Gibraltar, the Dardanelles and the Bosporus for Mediterranean and Black Sea trade.

Control over its maritime section stood at the core of the Danube Question, as the area had become an inter-imperial junction, situated on the political and symbolic border between the Russian and Ottoman empires, and regarded as a vital economic artery by traders from states like Austria, Great Britain, France, Sardinia and Greece. The Sulina Question, as presented in the previous chapter, was an object of conflict and cooperation between the governments of Russia, Austria and Great Britain. However, a larger Danube Question was forged in the diplomatic cauldron of $1854-1855$, when navigation through Russia's Danubian waters stood high on the agenda of the negotiators gathered in Vienna. As a diplomatic quagmire, it was extracted, during the Crimean War, from the larger Eastern Question, and stood in direct kinship with the international regime of the Black Sea or the political status of the Principalities of Wallachia and Moldavia.

This chapter aims to present the birth and growth of the Danube Question during the period $1855^{-1858}$ and to show how the diverging views in Europe's Concert of Powers over a strategic inter-imperial contact zone resulted in the formulation of new juridical principles, international norms and transnational institutions. Much scholarship in diplomatic history or the history of international relations has analysed such individual questions (the Straits Question or the Polish Question), but it is rarely possible to document the process that, at critical junctures, transforms political or economic interests into juridical principles. ${ }^{4}$

During that period, all seven signatories of the 1856 Paris Treaty and several other European cabinets agreed that 'internationalisation' was the proper

4 For a recent theoretisation of 'questions,' see Holly Case, The Age of Questions: Or, A First Attempt at an Aggregate History of the Eastern, Social, Woman, American, Jewish, Polish, Bullion, Tuberculosis, and Many Other Questions over the Nineteenth Century, and Beyond (Princeton and Oxford 2018). 
solution for turning the Danube into a stream of prosperity for the nations living along its banks and beyond them. There was something extremely appealing in this concept, which had survived murky revolutionary times and made it into international legislation in $1815 .{ }^{5}$ The 1815 Vienna Act stipulated that navigation along the entire navigable course of 'international rivers' (those touching on the territory of two or more states) had to be entirely free, not prohibited, 'in respect to commerce', to anyone. ${ }^{6} \mathrm{~A}$ liberal principle regarded international waterways as avenues of economic prosperity and of more peaceful interactions among nations. It stemmed from the laissez-faire doctrine popular at the time in industrialised Western Europe, but it had to stay in harmony with the sovereign rights of territorial powers, responsible for maintaining the navigability of transboundary waterways.

It took a long time to clarify what 'internationality' truly meant. Firstly, it implied the 'nationalisation' of sovereignty, which called for consistent domestic debates on the role of transboundary waterways for national development; policies of economic integration at regional and state level soon followed. Injured local communities had to be properly compensated and supported to find new opportunities in the more open economic environment of postNapoleonic Europe. Through complex diplomatic bargaining between riparian states, these rivers (the Rhine, the Elbe and the Weser) were eventually internationalised, meaning that navigation along their course followed more unitary rules, arbitrated by river commissions that acted as agencies of order, stability and security for seafarers and merchants of all nations.

When, in the context of the Crimean War, European diplomats contemplated extending the benefits of internationalisation to the Danube, none of the preliminary conditions that existed for other continental transboundary rivers were met. The Danube was navigable for almost 2,500 kilometres, two thirds of which passed through the German states of Württemberg and Bavaria, and through Habsburg territories. Bavaria and Austria had signed a treaty in

5 Georges Kaeckenbeeck, International Rivers: a Monograph Based on Diplomatic Documents (London 1918), 1-4.

6 For the 1815 decision and its results on the Central Commission for the Navigation of the Rhine, see Robert Mark Spaulding, 'Anarchy, Hegemony, Cooperation: International Control of the Rhine River,' online at https://www.ccr-zkr.org/files/histoireCCNR/21_anarchy-hegemonycooperation.pdf (visited on 15 August 2018); Hein A.M. Klemann, 'The Central Commission for Navigation on the Rhine, 1815-1914. Nineteenth Century European Integration,' in: Ralf Banken and Ben Wubs (eds.), The Rhine: A Transnational Economic History (Baden-Baden 2017), 31-68; Joep Schenk, 'The Central Commission for Navigation of the Rhine. A First Step towards European Economic Security?', in: Beatrice de Graaf, Ido de Haan and Brian Vick (eds.), Securing Europe after Napoleon. 1815 and the New European Security Culture (Cambridge 2019), 75-94. 
December 1851, which declared navigation on the Danube and its tributaries free for all nations, but they reserved for themselves the monopoly of a regular service of ships plying between the ports of their respective territorial waters. They also pledged to draft uniform regulations for trading and policing of navigation which were not, however, completed within the next four years. In 1855 Württemberg subscribed to this treaty, which was protracted in February 1856, ${ }^{7}$ at a time when the Paris Peace Congress was about to start.

If navigation on the Upper and Middle Danube was regulated according to such mutual agreements, the status of the Lower Danube remained to be clarified. Geographical impediments hindered navigation in several river sections, mainly through the Iron Gates gorge and in the Danube Delta, and territorial states in those regions were hardly able or willing to redress the situation. Russia, which owned the Danube Delta, gained little economic benefit from keeping the channel navigable, and in the previous quarter-century its officials had done little to effectively remove navigational barriers on the empire's southern border. The other riparian states along the Lower Danube were not really qualified to conduct the technical and normative works necessary to remedy navigation. The Sublime Porte did not have enough hydraulic expertise and financial resources to complete such a task, which was not economically vital for the northern Balkan provinces that the Ottoman government administered directly. The riparian states which could benefit most from engineering works in the Danube Delta were vassal Moldavia and Wallachia. The Principalities enjoyed a large domestic autonomy, the result of almost a century of successful anti-Ottoman campaigns by Russia. With a young bourgeois elite educated in Western Europe, they were fully engaged in the process of nation- and statebuilding. These processes further complicated their relations with both the Porte and Russia, the latter being the legal custodian of their special status.

When the question of internationalisation was formulated in $1854-1855$ by negotiators from Austria, France and Great Britain, they understood it in opposing ways, biased by their own political and economic interests in relation to the Lower Danube, especially its most economically productive part, the Maritime Danube. Just as the core of the Eastern Question was about maintaining a strategic balance of interests over the Turkish Straits, the Danube Question implied a similar objective - a neutralised and navigable Maritime Danube. Non-riparian powers asked for a voice in the regulation of river

7 For both documents, see Nouveau recueil général de traités, conventions et autres transactions remarquables, servant à la connaissance des relations étrangères des puissances et états dans leurs rapports mutuels, edited by Charles Samwer, vol. 16, no. 2 (Göttingen 1860), 63-74. 
navigation because of their vital interests in that area, and they wanted this in a direct way, not through their 'informal control' over the Ottoman government.

This narrative looks at the making of international law and how it was forged in diplomatic furnaces at the critical juncture that followed a large European war. Its general focus is at a systemic level, following the new regional geopolitical rearrangements concluded by Europe's top statesmen. They negotiated their countries' interests to the best of their abilities, and overall their bargaining tendencies show them to be rational actors. Once those principles were validated in the sacrosanct text of a peace treaty, a new conflict emerged. Experts were called in to explain the 'true meaning' of these principles. This proved extremely complicated, as statesmen had relied on imprecise geographical information about southeastern Europe, and the text of the 1856 Paris Treaty was ambiguous and controversial. When read by jurists, journalists or the wider public, still judging things with a bellicose mindset, it resulted in several phases of diplomatic conflict over the execution of the 1856 Paris Treaty. The construction of international law is a complicated process, especially when it involves elastic principles that amalgamate classical concepts of Roman jurisprudence and revolutionary innovations. The legal status of transboundary rivers was shaped from such subjective and relative interpretations, ${ }^{8}$ and Wurm and other public facilitators contributed to make them accessible to larger audiences.

It was in this complex legislative maelstrom that the Commission came into existence, kept alive by the vague or ambivalent principles included in the 1856 Paris Treaty. Before looking at the inner structure and proceedings of this international organisation (in Chapter 3), it is necessary to refer to the principles that supported it and to the interests that shaped these principles.

\section{Crimean War Diplomacy and the Internationalisation of the Danube}

The Congress of Paris (1856) represents a milestone in the international law of transboundary rivers. The final Peace Treaty was the result of preliminary negotiations that took place in Vienna in March 1855, in anticipation of the allies' successful military campaign in the Crimea. The preliminary draft was signed in Vienna on 1 February 1856 by the plenipotentiaries of Austria, Britain, France, the Ottoman Empire and Russia. Diplomatic bargaining on the Danube

8 Ralph W. Johnson, 'Freedom of Navigation on International Rivers: What Does It Mean?' Michigan Law Review 62 (1963-1964): 465-484. 
Question continued in late February and March 1856 . The final decisions were inscribed into five articles of the Paris Peace Treaty signed on 30 March 1856 by the seven contracting powers, which also included Prussia and Sardinia. ${ }^{9}$

Article 15 stipulated that the principles of the 1815 Vienna Treaty regarding the navigation of international rivers should also be applied to the Danube. This arrangement was considered to form part of Europe's public law, being placed under the protection of the seven signatory states. No toll could be levied founded solely upon the navigation of the Danube, and no duty could be charged on the goods carried by commercial vessels. Future regulations for policing and quarantining had to facilitate, as much as possible, the passage of vessels and no other obstacle was to hinder free navigation.

Articles 16 to 18 created the organs that were to carry out these principles. A European Commission of the Danube comprised of seven delegates (one for each contracting power) was

charged to designate and to cause to be executed the works necessary below Isatcha, to clear the mouths of the Danube, as well as the neighbouring parts of the sea, from the sands and other impediments which obstruct them, in order to put that part of the river and the said parts of the sea in the best possible state for navigation.

It was to determine fixed duties to be levied to cover the costs of the works and establishments that secured and facilitated navigation at the mouths of the Danube. The Commission had a term of two years to complete its tasks.

A second organisation was also created, the Riverain Commission, composed of four 'delegates' (one for each sovereign riparian state - Austria, Bavaria, the Ottoman Empire and Württemberg) and three 'commissioners' from the vassal principalities of Serbia, Wallachia, and Moldavia. The tasks of this organisation were: 1. to 'prepare regulations of navigation and river police'; 2. to 'remove the impediments, of whatever nature they may be, which still prevent the application to the Danube of the arrangements of the Treaty of Vienna'; 3. 'to order and cause to be executed the necessary works throughout the whole course of the river'; 4. after the dissolution of the European Commission of the Danube, to see to maintaining the mouths of the Danube and the neighbouring parts of the sea in a navigable state. The first two points were to be completed within a term of two years. The contracting powers of the 1856 Paris Treaty would then assemble in conference and pronounce the

9 The treaty in Congrès de Paris 1856 (Paris 1856). Articles 15 to 19 at pages 10-12. 
dissolution of the European Commission of the Danube, whose powers were to be taken over by the Riverain Commission.

Article 19 stipulated that, to ensure the execution of the regulations established by common agreement, each of the contracting powers had the right 'to station, at all times, two light vessels at the mouths of the Danube'.

As clear as they might seem, these provisions would cause intense diplomatic bargaining during the following couple of years. In fact, in 1859, Count Walewski, the French Minister of Foreign Affairs, acknowledged the ambiguity of articles 15 and $16,{ }^{10}$ a confession that was hardly a secret for the diplomats, experts and the public acquainted with the difficulties in the application of these stipulations.

Three hot issues occupied most of the negotiations between contracting parties in $1855^{-1856}$ and their solutions were, as detailed below, the seeds of subsequent disputes: a) the territorial termini of the internationalised river and Austria's struggle for 'special and exclusive advantages' over its Danubian watercourse; b) the right of non-riparian Great Powers to regulate the Danube's navigation; and c) Russia's riparian status and the territorial changes needed to provide additional guarantees of security to Danubian trade and shipping.

Two views existed in relation to the application of the 1815 principles to the Danube. At the Vienna ambassadorial conference, on 21 and 23 March 1855, one of the Austrian plenipotentiaries, Baron Prokesch-Osten, proposed that the 1815 principles were to be applied 'on the lower course of the Danube, starting from the point where the river becomes common to Austria and the Ottoman Empire, downstream to the sea'. In other works, the Austrian government wanted to internationalise a river section that was only tangent to Habsburg territorial waters and shared at that moment by the Ottoman Empire (together with its vassal states) and Russia. The logic behind this intention was to permit the river commission to focus on the problematic river section. As there were no complaints related to navigation upstream of the Iron Gates, the regime of the Middle and Upper Danube, regulated by mutual agreements between riparian states, needed no intervention. ${ }^{11}$

$10 \quad$ Henry Hajnal, Le droit du Danube international (The Hague 1928), 56, note 5 .

11 Annexes to Protocols nos. 4 and 5 of 21 and 23 March 1855, in Dimitrie A. Sturdza, Recueil de documents relatifs à la liberté de navigation du Danube (Berlin 1904), 15-17 and 21-23. 
The second view was that of France and Great Britain, presented by Count Walewski during the 6 March sitting of the Paris Peace Congress in 1856. The 1815 principles needed to be applied to the entire Danube and at its mouths, and the commissions appointed to regulate different aspects of its navigation had equal jurisdiction over the entire river course. Austria's Foreign Minister Buol saw no reason in extending such regulations to sections where no conflicts existed. ${ }^{12}$ His position was consistent with the hydro-hegemonic opinions of Emperor Franz Joseph and of other leading Austrian statesmen, as discussed in Vienna in February 1856. A clear distinction existed, according to Austrian interests, between the Lower Danube (primarily its maritime section) and the rest of the river. Franz Joseph argued that 'on the former all the Powers have equal rights, whereas, on the latter, only the Riparian States have got a say in the matter. ${ }^{13}$ Interferences by non-riparian actors upstream of the Iron Gates were intolerable, being in violation of Austria's national sovereignty.

Buol resumed the same considerations on 12 March, but British Foreign Secretary Clarendon rejected such a narrow interpretation that would have granted Austria unacceptable 'special and exclusive advantages.' ${ }^{14}$ In their message to Vienna, the Austrian plenipotentiaries in Paris referred to the difficulties in 'trying to keep the Upper Danube beyond the pale of the Conference and of the Commission about to be organized. Faced with strong opposition, the Austrians could not respond satisfactorily to 'some of the arguments with which they [the other plenipotentiaries] assailed us' and 'had a stiff fight against the French proposal which was strongly backed by Great Britain.15 In a private dispatch sent to Franz Joseph, Buol added that it was

a moral impossibility to assert that the principles of the [1815] Vienna Congress can never be applied to the Danube. Such an assertion would call forth a unanimous cry of displeasure, it might even frustrate the whole work of the Peace Conference, and rob us of the fruits of the freedom of the mouths of the Danube, with our possible exclusion from

12 Protocol no. 5 of 6 March 1856 , ibid., 25-27.

13 Hajnal, The Danube. Its Historical, Political and Economic Importance (The Hague 1920), 72; for Austria's position on the Danube Question during the Crimean War, see Emil Palotás, A nemzetközi Duna-hajózás a Habsburg-monarchia diplomáciájában 1856-1883 (Budapest 1984), 9-22 and idem, 'The Problems of International Navigation on the Danube in AustroHungarian Politics during the Second Half of the Nineteenth Century,' in Apostolos E. Vacalopoulos, Constantinos D. Svolopoulos and Béla Király (eds.), Southeast European Maritime Commerce and Naval Policies from the Mid-Eighteenth Century to 1914 (Boulder and Highland Lakes 1988), 99-101.

14 Protocol no. 8 of 12 March 1856, in Sturdza, Recueil de documents, 27-29.

15 Quoted by Hajnal, The Danube, 74. 
participation in the regulation of the Eastern question. [...] In conclusion, I humbly beg Your Majesty to bear in mind that it is better far to grant this freedom of our own will and accord, than to wait till we are forced to do so. Why should the conditions which have had such beneficial results on the Rhine and the Elbe not be introduced on the Danube?16

Austria's reluctance to include its part of the river in the arrangement had a lot to do with the shipping monopoly of the DDSG, the privileged steamboat shipping company, which the imperial government had extended until 1880. However, with the territorial changes Austria requested at the Lower Danube, Habsburg shipping companies could have encountered strong hostility in Ottoman waters. As Buol further added, the British delegates made it clear that unless the Upper Danube was declared free in accordance with the 1815 principles, 'the Lower Danube would be closed for Austrian ships, and also for the ships of the Privileged Danube Steam Navigation Company, as far as the Turkish frontier.' ${ }^{17}$

Franz Joseph finally consented, and on 18 March Buol informed his colleagues of Austria's acceptance of what can be termed 'one Danube policy'.18 The 1856 Paris Treaty stated that the 1815 principles with regard to the navigation of international rivers were to be applied to the entire course of the river. However, the interpretation of what this really meant remained an open question, as Austria soon reshuffled its Danubian policy. Equally, it tried to take advantage of this stipulation by building upon existing jurisprudence in relation to the structure and agenda of the river commissions appointed to regulate international waterways.

The Right of Non-riparian Countries to Regulate Danube Navigation

This was a corollary of the previous point, and the solution agreed to was a compromise between the two opposing views. In Prokesch-Osten's memorandum of 21 March 1855, a commission of sovereign riverain states touching on the Lower Danube (the Porte, Russia and Austria) was to remove the obstacles impeding navigation along the Maritime Danube. John Russell, one of the British plenipotentiaries at these preliminary negotiations, made it clear that

\footnotetext{
16 Ibid., 77 .

17 Ibid., 76 .

18 Protocol no. 10 of 18 March 1856, in Sturdza, Recueil de documents, 29.
} 
his country wanted, given its large interests in the trade of the Principalities, to be part of the institutional framework and of the agency that regulated navigation along this river section. ${ }^{19}$

The model of two separate river organisations was introduced and defining their tasks and executive mandates was the object of heated bargaining between Austria and its western allies. The European Commission was established with a limited term, both chronologically and geographically, as an embodiment of Europe's collective interests in a strategic inter-imperial junction. The European Commission was mainly envisaged as a temporary technical committee that would intervene in an emergency to remove acute navigational obstacles along the Maritime Danube. The Austrians insisted on its limited scope and on the independence of the Riverain Commission, whereas the Brits managed to convince Vienna that the European Commission was only to be disbanded with the mutual consent of all contracting powers. ${ }^{20}$ As for the Riverain Commission, it was to include all riparian states (sovereign or vassal) stretching along the navigable course of the Danube. The provisions related to these two organs marked a significant deviation from the 1815 Vienna Act, which reserved no place in river commissions for non-riverain states although the representatives of non-riparian powers (such as Lord Clancarty for Britain) had contributed to drafting those rules in Vienna.

The extension of the 1815 principles to the Danube, their inclusion in Europe's public law and the vague role Britain and France were able to save for themselves in 1855 and then again in 1856 established a legal precedent used to justify the participation of non-riparian states in the regulation of rivers where they had major economic interests. This marked a new view on the navigation of international waterways. Equality of treatment for riparian and non-riparian countries alike was included in conventional laws that sovereign territorial powers could grant for the benefit of all interested parties. Perfect equality for all flags was regarded as a more liberal understanding of the freedom of navigation, expressly conferred through an international agreement. ${ }^{21}$

The special position of riverain states was implicit and respected, but there were cases where representatives of non-riparian states had to be accepted into river commissions. Sometimes, as in the situation of the Lower Danube, the sovereignty of riparian states had to be limited in their own interest, as the presence of external actors could either minimise friction between territorial

\footnotetext{
19 Protocol no. 4 of 21 March 1855 and Prokesch-Osten's Memorandum, ibid., 12-17.

20 Protocol no. 5 of 23 March 1855 and the development of the second point, ibid., 17-23.

21 Ruth E. Bacon, 'British and American Policy and the Right of Fluvial Navigation,' British Yearbook of International Law 13 (1932): 77.
} 
powers or provide them with expertise which they did not possess. ${ }^{22}$ It was, in many ways, an internationally legalised technical intervention.

\section{Removing Russia from the Maritime Danube - Territorial Cessions, Imperial Honour and Revisionism}

In an early stage of the Eastern Crisis, European statesmen were convinced that Russia's 'interested indifference' was to blame for the improper conditions of navigation in the Danube Delta. In Prokesch-Osten's memorandum (21 March 1855), one of the solutions envisioned by the Austrians was to neutralise the Danube Delta and repeal quarantine procedures along the Sulina branch. Russia could keep its jurisdiction over the subjects of the demilitarised zone and the Habsburgs would guarantee free navigation by establishing their own garrison at the mouths of the Danube. It meant, in fact, to maintain the status quo, as Austria had occupied Sulina in 1855 and was imposing its own legislation in the area. The western allies, however, intended to cancel several stipulations of the 1829 Adrianople Treaty, with the view of returning the Danube Delta to the Ottoman Empire. ${ }^{23}$

An additional safety measure for avoiding future malign Russian impositions was to force an ampler territorial rectification at the Lower Danube. In exchange for the Russian territories under allied occupation, Russia was asked to accept a border change in its southern province of Bessarabia, with the view of returning (at least a part of) it to Moldavia and thus cease being riverain to the Danube. The intention was discussed at Vienna and included, with clearer geographical limits, in the text of an Austrian-French agreement dated 14 November $1855{ }^{24}$ The British considered this part of the Habsburgs' policy to secure a safer military border with Russia in expectation of the annexation of Moldavia and Wallachia, which Austrian troops had occupied in the summer of $1854{ }^{25}$ There were several downsides to such territorial expansion in

\footnotetext{
22 Lionel William Lyde, 'The International Rivers of Europe,' Geographical Journal 54.5 (1919): 310.

23 Protocols nos. 4 and 5 of 21 and 23 March 1855 and their annexes, in Sturdza, Recueil de documents, 12-23.

24 Winfried Baumgart (ed.), Akten zur Geschichte des Krimkriegs, series I, vol. 3, Österreischische Akten zur Geschichte des Krimkriegs. 10. September 1855 bis 24. Mai 1856 (Munich 1979), 106 (doc. no. 34).

25 Ibid., series III, vol. 4, Englische Akten zur Geschichte des Krimkriegs, 10. September 1855 bis 23. Juli 1856 (Munich 1988), 353-354 (doc. no. 184).
} 
the Danube Delta and in Bessarabia, but for London (and Paris equally) it was vital to keep Vienna close to the western alliance. ${ }^{26}$

The demand was officially submitted to Russia's Chancellor Nesselrode in December 1855. The ultimatum mentioned, among other things, the neutralisation of the Black Sea, territorial cessions in Bessarabia and the Danube Delta, and free navigation on the Danube. The Russians tried to bargain and avoid the loss of Bessarabia, but a second ultimatum followed in January 1856 . On 15 January, after an extraordinary meeting with his councillors, Tsar Alexander II accepted the allies' terms and Russia's participation in the peace negotiations convened in Paris. ${ }^{27}$

During the formal and informal meetings held in the French capital, Russian plenipotentiaries tried to save as much of Bessarabia as possible. Tsar Alexander's honour was at stake, and Russian dignity was defended by Emperor Napoleon III, who was interested in keeping Russia as a strategic partner for France's political ambitions in the Eastern Question. Napoleon III felt it was a good moment to prove his sympathy and persuaded his British allies to renegotiate the Bessarabian border. ${ }^{28}$

From London, Prime Minister Palmerston instructed his diplomats to follow an uncompromising line of action and preserve the strategic relevance of the territorial cession: Russia must be removed from the Danube. With repeated messages to Paris to stick to their agreement and thinly-veiled threats that Britain had 'the means to continue the war' by itself, Palmerston convinced Napoleon III to send the Russian cabinet a new ultimatum calling for the immediate acknowledgment of the territorial cession in Bessarabia. However, the French Emperor managed to elicit several concessions which further reduced the territory that Russia would retrocede. ${ }^{29}$

The compromise was presented to the Congress on 10 March 1856, and four days later Count Orlov, one of the Russian plenipotentiaries, announced his government's agreement to the territorial rectification. ${ }^{30}$ Although Russia lost less territory than originally planned, the strategic objective of removing it from the Lower Danube and the lower section of the Prut River was achieved. This provision was included in Article 20 of the Peace Treaty, which stated that

\footnotetext{
26 Ibid., 399-400 (doc. no. 212).

27 Harold Temperley, 'The Treaty of Paris of 1856 and Its Execution [I],' Journal of Modern History 4.3 (1932): 389-394.

28 The National Archives of the United Kingdom (TNA), Public Record Office, FO 27/1164, f. 56-59 \& 78 (Earl of Clarendon to Viscount Palmerston, Paris, 23 and 25 February 1856).

29 Temperley, 'The Treaty of Paris,' I: 404-405.

30 Protocols 7 and 9, 10 and 14 March 1856, Congrès de Paris, 65-68 and 74-77.
} 
the retrocession of Southern Bessarabia was meant 'to better secure the freedom of navigation of the Danube. ${ }^{31}$

The territorial loss in Bessarabia and the neutralisation of the Black Sea were the most humiliating stipulations of the 1856 Treaty, making Russia a revisionist state in relation to the new international status of the river. ${ }^{32}$ As mentioned above, and as an exception to the neutral regime of the Black Sea, the seven contracting powers were allowed to station two light warships at the mouths of the Danube to ensure the observance of all international navigational regulations. ${ }^{33}$

Russia grudgingly accepted the loss of Southern Bessarabia, but soon tried to speculate on the many ambiguities of the ${ }_{185} 6$ Paris Treaty. Two issues were used by Chancellor Gorchakov as the spike meant to split the western alliance and by Palmerston as a barometer of Britain's relations with France: the status of Serpent Island and sovereignty in the Danube Delta.

The 1856 Treaty included no reference to Serpent Island, a small rock about 20 miles off Sulina. Considering that their country remained the rightful owner of this territory, the Russians dispatched to the island a small garrison for restoring the local lighthouse, a crucial landmark for the seafarers who sailed towards the Danube or the ports in southern Ukraine. However, the island had already been occupied by Ottoman soldiers, supported by the British navy. ${ }^{34}$

In the subsequent diplomatic dispute over the rock, Walewski thought that it had no strategic value: the Russians could keep it, while the lighthouse would be managed by the Danube Commission. Palmerston rejected Russia's claim. The island had to stick to the Danube Delta, which had been taken from Russia. The British fleet was ordered to defend a sovereign territory of the Porte and to remove the Russian garrison. The Russian cabinet requested a reconvening of European negotiators and a collective decision of the seven contracting powers on the fate of Serpent Island. With a visible rapprochement in Russian-French relations, Britain tried to avoid such a complication. ${ }^{35}$

$31 \quad$ Ibid., 12-13.

32 Barbara Jelavich, The Ottoman Empire, the Great Powers, and the Straits Question. 1870-1887 (Bloomington 1973), 9.

33 Congrès de Paris, 12.

34 W.E. Mosse, 'Britain, Russia and the Question of Serpents Island and Bolgrad. Two Incidents in the Execution of the Treaty of Paris,' Slavonic and East European Review 29.72 (1950): 86-131 (the same text is included in idem, The Rise and Fall of the Crimean System, 1855-71: The Story of a Peace Settlement (London 1963), 55-104); Dumitru Vitcu, 'The Treaty of Paris and the Bolgrad Crisis of Its Execution,' Anuarul Institutului de Istorie «A.D. Xenopol» 43-44 (2006-2007): 335-353.

35 British correspondence on both the Serpent Island and Bolgrad cases was published in several blue books: Correspondence Relative to the Execution of the Treaty of Paris, vol. $\mathrm{I}-\mathrm{v}$, 
On 6 January 1857, the seven plenipotentiaries concluded a new agreement to resolve the pending issues related to the execution of the 1856 Treaty: Serpent Island was returned to the Porte, and Russia received territorial compensations in the area of Lake Yalpuk, but without having any contact with the Danube. ${ }^{36}$

Another decision intended to clarify and simplify the new status of the Maritime Danube was to transfer the Danube Delta from Moldavia to the Ottoman Empire. The ambiguity lay in the text of article 21 of the 1856 Paris Treaty, which stipulated that the territory retroceded by Russia was to be annexed by Moldavia, under the sovereignty of the Sublime Porte. ${ }^{37}$ The issue was complicated by the fact that Moldavia, an autonomous principality, was seeking political union with Wallachia as a way of establishing an independent buffer state between Russia and the Ottoman Empire. In August 1856, the Porte officially informed the Moldavian and Wallachian governments of the decisions taken in Paris, including taking into possession the Danube Delta. National elites in the Principalities protested, and a memorandum signed by Wallachian General Gheorghe Magheru was submitted to the seven signatories of the Paris Treaty. ${ }^{38}$ In order to avoid any future disputes, on 6 January 1857 European plenipotentiaries changed the status of the Danube Delta, placing it under the direct sovereignty of the Porte. ${ }^{39}$

All these arrangements were later included in an appendix to the 1856 Paris Treaty, signed on 19 June $1857 .^{40}$ The territorial complications connected to the Danube Question seemed resolved. There were, however, some vying interpretations of the 1856 juridical innovations that required the attention of legal experts and diplomats throughout Europe.

April 1856-January 1857 (London 1856-1857). French sources are preserved in the Archive of the French Foreign Ministry, Fond Mémoires et documents, Roumanie, vol. IV, 18561857. Some documents were published by Lucia Taftă, 'Marile puteri și Gurile Dunării în secolul al XIX-lea,' Revista Istorică 22.1-2 (2011): 61-69 and Constantin Ardeleanu, 'Sfârșitul Războiului Crimeii și chestiunea Basarabiei (1856),' in: Gheorghe Cliveti and Gheorghe Cojocaru (eds.), Basarabia - 1812: Problemă națională, implicații internaționale: materialele Conferinței Ștïnțifice Internaționale 14-16 mai 2012, Chișinău-Iași (Bucharest 2012), 501-516.

36 The protocol of 6 January 1857 in Hertslet's Commercial Treaties: A Collection of Treaties and Conventions, Between Great Britain and Foreign Powers, vol. 10 (London 1859), 553-554.

37 Congrès de Paris, 13.

38 Spiridon G. Focas, The Lower Danube River: In the Southeastern European Political and Economic Complex from Antiquity to the Conference of Belgrade of 1948 (Boulder and New York 1987), 245-246.

39 Hertslet's Commercial Treaties, 10, 553-554.

40 Ibid., 959-961. 
The Riverain Commission and the Making of the 1857 Navigation Act

According to the 1856 Paris Treaty, two river commissions were to convene readily and start the urgent task of regulating Danube navigation. The Commission was to take care of removing physical obstacles along the Maritime Danube, and its seven members assembled in the Moldavian port of Galați, the largest 'civilised' city near the Danube Delta. The first meeting took place on 4 November 1856 and its early proceedings will be detailed in the next chapter.

The Riverain Commission, a permanent institution composed of representatives of the seven riparian states, was to 'prepare regulations of navigation and river police' for the entire course of the Danube, and to 'remove the impediments, of whatever nature they may be, which still prevent the application to the Danube of the arrangements of the Treaty of Vienna'. Its members gathered in Vienna, and the first meeting took place on 29 November 1856. The Austrian delegate, François Serafin Blumfeld, a councillor at the Ministry of Commerce, Industry and Public Works, was elected president of the conference. Most of his colleagues had some experience in river navigation, either with a focus on international law or with riverain trade and hydraulic works.

For expediency, they decided to complete the regulation of navigation and then draft the provisions for river policing. Activities were divided into three committees (free navigation, abolition of privileges and navigation patents; financial provisions and customs regulations; and securing Danube's navigability), ${ }^{41}$ but all plenipotentiaries focussed on the hot issue: how to harmonise national rights with the internationalised status of the river.

On 22 December 1856, after three sittings, the Wallachian commissioner, Nicolae Rosetti, reported to Bucharest about the view supported by the representatives of Bavaria, Württemberg and Moldavia (François Sebastien de Daxenberger, Adolfe Müller and Panait Donici respectively), who advocated absolute freedom of trade and navigation on the Danube, as it resulted from a literal and liberal interpretation of the Paris Treaty. This meant to allow 'foreign nations to lease establishments and wharves on the Danube's banks' and to grant them equal rights for inland navigation. Austria's Blumfeld rejected this opinion, as being highly detrimental to the economic interests and sovereign rights of riparian states. Rosetti acknowledged that, for the Principalities,

41 Donau-Schifffahrtsacte - Acte de navigation pour le Danube. Donaudampfschifffahrts Acte \& Protokolle 1856-1857 (Vienna 1856-1857), Protocols 1 to 3, 29 November, 3 and 10 December 1856 - ibid., $1-8$. 
absolute freedom, even on a limited section of the Lower Danube, could be 'extremely useful' for their 'trade, civilisation and future political development'. ${ }^{42}$

But he was not sure if such an opinion would be appropriate in that political context. It was the first time that representatives of the Principalities took part, with the consent of their suzerain power, in international diplomatic negotiations. It was an historic success for their national struggle, and more was expected to come in the following months. The Principalities had been governed since June 1856 by kaymakams, governors appointed by the Porte to execute the provisions of the Paris Treaty relative to their future organisation. Moldavia and Wallachia were to enjoy 'independent and national administration', delegates of the European powers would enquire into their situation, and nationwide representative assemblies (Ad hoc Divans) were to state the popular views on the definitive organisation of the two states. The Principalities were still occupied by Austrian troops and were the scene of intense political battle. National forces fought for convincing their fellow citizens and European powers of the benefits of a political union of the Principalities, a solution warmly supported by Napoleon III and as firmly opposed by Austria and the Sublime Porte. ${ }^{43}$

In this volatile political context, Rosetti had to be extremely careful. He needed to follow the instructions of his government, to stay close to the Ottoman delegate and keep an eye on the political intrigues that were unfolding in Vienna. He waited for the instructions of his government, but also studied the behaviour of the Ottoman delegate, Garabed Artin Davoud Oghlou, and wondered secretly how he could vote against the Austrian delegate, whose opinion was supported by the actual situation of navigation on Europe's rivers. Inactivity seemed a better choice in those circumstances: 'Until now I'm in no hurry; on the contrary, I slow down, and I avoid working.. ${ }^{4}$

In January 1857, after receiving instructions from Istanbul, Davoud Oghlou presented his government's greatest concern - the various interpretations of the Paris Treaty concerning the collection of navigation duties. Article 15 stated that no toll could be levied founded solely upon the navigation of the Danube, and no duty could be charged on the goods carried by commercial vessels. As it owned a long river section where important hydraulic works had to be carried out, the Porte insisted that it had the right to collect a regular tax on shipping,

42 Ioan C. Filitti, 'Un raport diplomatic muntean din 1856,' Revista Istorică 10.4-6 (1923): $75^{-79 .}$

43 For this, see the classic accounts of W.G. East, The Union of Moldavia and Wallachia, 1859, an Episode in Diplomatic History (Cambridge 1929) and T.W. Riker, The Making of Roumania: A Study of an International Problem 1856-1866 (London 1931).

Filitti, 'Un raport': 79 . 
intended to cover the costs of maintaining river navigability. He also defended the Austrian view that there existed a clear distinction between inland and maritime navigation and considered that the first had to be reserved to riparian states. This fact derived from 'their sovereign rights over the Danube', as clearly stated in the 1815 Vienna Act. ${ }^{45}$

After 31 sessions, the parties finally reached a compromise in late August 1857, when the text of a Navigation Act, with a total of 47 articles, was completed. It removed all exclusive privileges which prevented the application on the Danube of the 1815 Vienna Act, and declared that navigation between river and sea was free and equal to vessels of all nations. However, inland navigation was 'reserved for the vessels of riparian countries'. The rest of the document referred in detail to public safety measures, the categories of tolls levied by riparian states, quarantine regulations, procedures in cases of shipwrecks, and other shipping accidents and piloting regulations etc. The Riverain Commission was to appoint experts who would navigate along the Danube, study the nature of the physical obstacles hindering navigation and indicate the hydrotechnical works necessary for removing them. The Riverain Commission would analyse these technical results, but the actual works had to be done by riparian states, as in the case of the Central Commission for the Navigation of the Rhine. The Navigation Act was to come into force starting on 1 January $1858 .{ }^{46}$

Beyond drafting this very useful document, a real benefit of this expert meeting was that the Riverain Commission managed to collect a vast amount of knowledge on the Danube. From the beginning of their activity the seven plenipotentiaries required from their governments maps of the river and of its banks, details on physical obstacles, statements of expenditure recently incurred by their states in constructions and works for the improvement of Danube navigation and description of duties paid on navigation. ${ }^{47}$ This shared expertise seemed to represent a good start for regulating navigation along a river that, by 1857 , still lacked a reliable map.

In September 1857, the Riverain Commission met to work on river policing regulations, and again the convention of the Rhine and Elbe, as well as a Bavarian project for the Danube, served as initial models. The representatives of Württemberg and Moldavia were appointed to prepare a preliminary version, a part of which was drafted within a fortnight. Moldavia's Ludovic Steege was assisted by Georg Gottlieb Schirges, the archivist of the Central Commission for the Navigation of the Rhine in Mainz, whereas Württemberg's

45 Annex to protocol no. 5, 7 January 1857 - Donau-Schifffahrtsacte, 23-27.

46 Sturdza, Recueil de documents, 51-66.

47 Protocols 2 and 3, 3 and 10 December 1856 - Donau-Schifffahrtsacte, 5-7. 
Müller got precious input from a certain Meyer, an inspector of the DDSG. ${ }^{48}$ The three initial chapters (construction, equipment, crew and loading of vessels; duties of ship captains and crews; and piloting) were to be completed after getting the feedback of riverain states on details such as: laws, regulations and customs on fluvial police, where they were applied, to what types of vessels, other interested administrative and technical authorities or companies, places where piloting was necessary, and current rules for piloting and pilots. ${ }^{49}$

But the apparent peace of the Riverain Commission was ruined on 7 November 1857, when plenipotentiaries assembled to vote on the Navigation Act. Serbia's Filip Hristic was instructed by his government to demand the modification of several articles, but all three commissioners (from Serbia, Wallachia and Moldavia) were refused the right to sign the document on an equal footing with the delegates of independent states. The commissioners protested and concluded separate minutes of the meeting, to reflect their own view on what had happened. ${ }^{50}$ Eventually, stating that it was 'natural to sign together an act that was negotiated together', they were given the right to sign, but the act had only four original texts, as vassal states would receive copies from the Porte. These tensions were exploited by the national(ist) parties in the Principalities, which required the support of the ambassadorial conference to be convened in Paris in 1858 for deciding on the future organisation of Moldavia and Wallachia. ${ }^{11}$ But, by then, the non-riparian powers represented in the European Commission had their own complaints in relation to the works of the Riverain Commission and it suited them perfectly to add some more grievances from three diplomatically 'silenced voices'.

\section{8}

A Juridical Conflict between 1815 and 1856

The developments of the Crimean War attracted many western capitalists to invest in the economic resources of the Black Sea area. By the end of the conflict, tens of British, French and Austrian entrepreneurs were busy proposing the construction of bridges, railways, canals and harbours. The Lower Danube and its tributaries figured on the investment maps of such capitalists, as fluvial

\footnotetext{
48 Protocol 33, 16 October 1857 - ibid., 241-242.

49 Ibid., 243-255.

$50 \quad$ Focas, The Lower Danube River, 100.

$5^{1}$ Mihail Kogălniceanu, Documente diplomatice, edited by George Macovescu, Dinu C. Giurescu and Constantin I. Turcu (Bucharest 1972), 70-71.
} 
steam navigation companies, harbour infrastructure and railways to connect the Danube with inland territories seemed a very profitable business.

Martin Samuelson, a large investor in shipbuilding in the British port of Hull, came up with the idea of establishing a company to run steamers between Britain and the Black Sea, and further upstream the Danube. In March 1857, Samuelson wrote to the British Foreign Office for clarification on the grant he needed from the Viennese government to navigate in Austrian territorial waters. Little information was available at the time and Ambassador George Hamilton Seymour could get no details in Vienna. ${ }^{52}$

By March 1857 the Riverain Commission had already concluded ten protocols, though its proceedings were conducted with much confidentiality. The European Commission sent copies of their own documents to Vienna, ${ }^{53}$ but the Riverain Commission refused to engage in any institutional correspondence with its organisational sibling. ${ }^{54}$ However, several plenipotentiaries later stated that their governments authorised them to communicate and exchange with the European Commission details and protocols of their meetings. ${ }^{55}$

Further complications arose as the commissions looked for ways to execute their tasks. In April 1857, the British Foreign Office drafted a detailed 'Memorandum on the Danubian Commissions under the Treaty of March 30, 1856. The document provided a legal interpretation of the proceedings of the two organs, mainly of the one in Galați, whose activities came into direct collision with Ottoman sovereign rights in the Danube Delta. The author considered that both institutions should report to a future ambassadorial conference on their results, 'not, however, that the Conference should ratify or confirm what they have done, but should merely record the fact of its having been done. ${ }^{56}$ When communicated to Buol in Vienna, the Austrian minister fully concurred with this opinion. ${ }^{57}$

By June, information on the Riverain Commission's preliminary decisions made Ambassador Seymour worry that by reserving inland navigation for themselves, riparian states gave rise to a legal issue. Article 109 of the 1815

$5^{2}$ TNA, FO 78/3242, unnumbered (hereafter unn.) ('Mem. as to Austrian grants for trade upon the Danube,' 5 March 1857 and Ambassador George Hamilton Seymour to Clarendon, Vienna, 23 March 1857).

53 National Archives of Romania, Galați Branch, Protocols of the European Commission of the Danube (hereafter PECD), Protocol 10, 12 January 1857.

54 Protocol 14 of the Riverain Commission, 11 March 1857 - Donau-Schifffahrtsacte, 85-86.

55 Protocol 15, 30 March 1857 - ibid., 95-96.

56 TNA, FO 78/3242, unn. ('Memorandum respecting the Danubian Commission under the treaty of March 30, 1856,' Foreign Office, London, 23 April 1857). Ibid. (Seymour to Clarendon, Vienna, 25 May 1857). 
Vienna Act seemed to be in direct contradiction with the stipulations of the Paris Treaty, 'in which case I submit that the more modern supersedes the more ancient stipulation, that 1815 must give way to 1856.58 The French ambassador to Vienna, François-Adolphe de Bourqueney, was actively involved in defending the view that the regulation set out by the Riverain Commission was merely a draft which had no validity until sanctioned by the Concert of Europe in an ambassadorial conference. ${ }^{59}$

Analysed by the British Privy Council of Trade in a document signed by Sir James Emmerson Tennent, the permanent secretary of the Board of Trade, the Riverain Commission's preliminary stipulations were considered injurious to British interests, as their effect 'will be practically to exclude Great Britain from any commercial advantages in this branch of trade'. There were ample grounds for contesting the validity of the very principles upon which these regulations had been framed, as the 1815 Vienna Act had been mistakenly applied on the Rhine, the Elbe and other European rivers. ${ }^{60} \mathrm{~A}$ similar opinion was formulated when European cabinets got a copy of the Navigation Act drafted by the Riverain Commission in late August 1857. An additional reason to consider its basic principle (inland navigation reserved to riverain states) illegal was the fact that Britain and other countries had rights resulting from bilateral treaties, such as those concluded in 1838 between Britain, Austria and the Porte. ${ }^{61}$

In Istanbul, Ambassador Stratford Canning tried to persuade the Porte to postpone signing the 1857 Vienna Navigation Act, but Foreign Minister Aali Pasha defended his acceptance with the answer that the Ottoman signature would not invalidate a collective decision of all signatories of the Paris Treaty. ${ }^{62}$

A new analysis by the Privy Council of Trade insisted on the legal conflict between the 1815 principles and how they were implemented on Europe's international rivers. Britain could not acquiesce to the application of principles to the Danube that it considered 'to be at variance with the proper construction of that Treaty and which would defeat the primary commercial objects of the western powers in providing by the Treaty of Paris for the free navigation of the Danube. 63

\footnotetext{
58 Ibid. (the same, 27 June 1857 ).

59 Ibid. (the same, 14 and 27 July 1857 ).

6o Ibid. (Report from the Office of Committee of Privy Council for Trade, London, 30 July 1857).

61 Ibid. (Report from the Office of Committee of Privy Council for Trade, London, 19 October 1857).

62 Ibid. (Stratford Canning to Clarendon, Istanbul, 8 October 1857).

63 Ibid. (Report from the Office of Committee of Privy Council for Trade, London, 28 October 1857).
} 
The signing of the Navigation Act in 'unpleasant circumstances' gave nonriparian powers additional reasons to contest the validity of the agreement. ${ }^{64}$ Britain contested three main points (the document's silence on Danube's tributaries, the exclusion of non-riparian states from inland navigation, and its overriding existing treaties), ${ }^{65}$ but it also used diplomatic channels to bargain for a compromise. Buol spoke of 'sovereign rights and national dignity' and used the very arguments of the Foreign Office: an ambassadorial conference could only take note of the regulation. However, he insisted that more could be gained through mutual bargaining. ${ }^{66}$

The Austrian position was communicated in a long memorandum, whose main argument stemmed from the legal authority of the 1815 Vienna Act. Non-riparian states could have a say only in the Danube Delta, where vital hydrotechnical works had to be carried out through a collective effort by Europe. This was an extraordinary and transitory measure, and the area was later to return to the application of common law. The 1856 Treaty mentioned the special position of riverain states, and their view was similar to the execution of the same principles on the Elbe, Weser or Rhine. The Viennese cabinet also rejected the right of an ambassadorial conference to validate the Riverain Commission's regulations, as such an acceptance would infringe upon the sovereignty of riparian states. It would be a gratuitous humiliation to have four sovereign states wait for formal approval from the plenipotentiaries of five other states before ratifying an international convention they concluded, relative to the navigation of a river they shared' ${ }^{67}$

The Porte stood by its decision to ratify the Navigation Act, despite increasing pressure from Britain and France to reject it. In a memorandum sent to London on 16 January 1858, Fuad Pasha considered that the Navigation Act corresponded entirely with the principles of the Vienna Congress on the issue of fluvial navigation. Similar riparian commissions were consecrated on Europe's rivers by decisions of riparian countries, which needed to defend their sovereign rights and national interests. ${ }^{68}$

In the following months, the other contracting powers provided their interpretation of the Navigation Act, making this a very interesting case of international juridical bargaining. The French memorandum questioned if the 1815 Vienna principles 'necessarily implied the exclusion of non-riparian flags

64 Ibid. (Seymour to Clarendon, Vienna, 8, 11 and 18 November 1857).

65 Ibid. (Report from the Office of Committee of Privy Council for Trade, London, 5 December 1857).

66 Ibid. (Seymour to Clarendon, Vienna, 9 and 16 December 1857).

67 Ibid., FO 881/731 (version printed for the use of the Foreign Office on 22 April 1858).

68 Ibid., FO 881/734 (version printed for the use of the Foreign Office on 23 April 1858). 
on the rivers subjected to the free regime. At the same time, the $183_{11}$ Mainz Convention which defined the rights of the Central Commission for the Navigation of the Rhine could not be considered as 'the invariable and compulsory rule' ${ }^{69}$

The Russians contested the very basis of Austria's position: that of comparing the Danube with any other international river. The Danube was, politically and economically, special, as 'the interests of the West are linked by the Danube with those of the Levant'. The Riverain Commission's regulations and the dissolution of the European Commission needed the unanimous adhesion of all contracting powers, as it required common supervision of Danubian navigation adopted by the Concert of Powers. The 1857 Vienna Act could not be the proper rule for the Danube, whose lower course from Belgrade to the Black Sea traversed riparian states with special social and political situations. Serbia, Wallachia and Moldavia were vassal states which had the Ottoman Empire as suzerain and Christian Europe as guarantor. The 1815 Vienna principles had been modified according to the political conditions from the Lower Danube, and Europe had to safeguard their rights which had not been properly defended in Vienna in $1856-1857 .{ }^{70}$

The Sardinian government referred to the 1857 Act's problems of form and content. The ambassadorial conference had the right and obligation to examine the Riverain Commission's work, to modify and even reject it, if it was not in accordance 'in its entirety or in part with the dispositions of the Paris Treaty and its spirit'. Free navigation was one of the guarantees of peace, and the signatory powers were obliged to see to its application. The 1857 Vienna Act was contrary to the 1856 Paris Treaty (as it raised obstacles to Danubian navigation) and to the rights granted by the Porte to several powers either by public treaties or by customary law. ${ }^{71}$

Finally, the Prussian memorandum defended the right of an ambassadorial conference to analyse and veto the 1857 Navigation Act, whose articles were contrary to the mutual interests of European powers. ${ }^{72}$

The diplomatic dispute was exacerbated by its presentation in the daily press and by public positions of nationalist agitators or expert voices, such as Wurm. Rarely did such authors differ from the official position of their governments. Analysis of this journalistic dispute reveals the increasing public interest in decision-making processes involving such delicate concepts as nation, sovereignty and dignity.

69 Ibid., FO 881/732 (version printed for the use of the Foreign Office on 23 April 1858).

$70 \quad$ Ibid., FO 881/736 (version printed for the use of the Foreign Office on 27 April 1858).

71 Ibid., FO 881/735 (version printed for the use of the Foreign Office on 23 April 1858).

72 Ibid., FO 881/733 (version printed for the use of the Foreign Office on 23 April 1858). 
In late 1857 - early 1858 when western governments pressured the Porte to refuse the ratification of the Vienna Navigation Act, the British press covered the story in plenty of detail. A correspondent of London's The Times reported from Vienna on 29 December 1857, condemning the narrow view of riverain states. As for their great privileges on rivers such as the Elbe and Weser, 'the sooner they are abolished the better it will be for Europe at large. ${ }^{73} \mathrm{~A}$ week later, quoting an Austrian newspaper that portrayed the Habsburgs as defenders of the Porte's integrity and sovereignty, the reporter believed that the Viennese cabinet would eventually acknowledge the justice of western claims. ${ }^{74}$ Faced with Austrian 'illiberalism' and 'selfishness', Britain and France had to stay strong. By yielding in this matter

would they not appear ridiculous in the eyes of surrounding nations? Would they not have been used as "cat's paws" by Austria? They dislodged the Russians from the mouths of the Danube, but it was not for the advantage of Austria and the other Riverain Powers alone that they undertook and accomplished such a difficult task. England, France, and Russia would do well to put the spur into the flank of the European Commission for the navigation of the Danube will not be free until its labours are completed. ${ }^{75}$

Media coverage remained consistent throughout the first half of 1858 , and the daily press was fed with 'leaks' of the different memoranda drafted by interested governments. Several brochures were published throughout Europe, among which a French memorandum with a detailed historical and juridical presentation of the entire issue. ${ }^{76}$ Wurm's collection of articles published in his second brochure was perfectly timed.

\section{Riparians vs. Non-riparians at the 1858 Paris Ambassadorial} Conference

In these circumstances, diplomatic discussions on the Navigation Act sustained such public positions. The Paris conference convened in 1858 to complete the future organisation of the Principalities of Moldavia and Wallachia,

\footnotetext{
73 'Austria,' The Times, 1 January 1858: 7.

74 Ibid., 7 January $1858: 7$.

75 Ibid., 11 January 1858: 8.

76 Mémoire sur la liberté du Danube et sur l'acte de navigation du 7 novembre (Paris 1858).
} 
which were eventually granted a constitution and allowed to have a formal union.

The Danube Question was discussed during the sittings of 9, 16 and 19 August 1858. On 9 August, the 1857 Navigation Act was officially communicated to the European plenipotentiaries. Discussions on its contents started one week later and Britain led the 'alliance' of non-riparian interventionists. Cowley, Britain's Ambassador to Paris, objected to the Act for not including proper guarantees for safeguarding free trade and navigation on the Danube. As the document was 'conceived in a more exclusive spirit, and one more favourable to the Riverain States', Cowley demanded the abolishment or substitution of about a third of its articles and wanted subsequent alterations of the Act to have the consent of all contracting powers. Walewski backed him on these points and further required the extension of free navigation to Danube's tributaries. The Prussian, Russian and Sardinian delegates were in favour of all the proposals of non-riparian states. ${ }^{77}$

The Austrian delegate, Baron Hübner, defended the legality and validity of the 1857 Act. He referred to the principles and stipulations of the 1815 and 1856 peace settlements, which did not imply an absolute freedom of navigation for the flags of all nations. With ample references to the proceedings of 1815, he considered that the 1857 Vienna Act maintained the clear distinction between riverain and non-riverain states which was upheld in the 1856 Paris Treaty. Only the Danube Delta area received an extraordinary status, and the Maritime Danube remained completely free for the commercial traffic of all flags. Citing the cases of the Rhine and the Elbe, he considered that absolute freedom for all flags could only be applied to the Maritime Danube. ${ }^{78}$

The Ottoman plenipotentiary also defended the Act drafted in Vienna in 1857, which conformed with the peace treaties of 1815 and 1856 . Hübner and Fuad Pasha consented to forward all opinions to their governments to be taken 'into consideration, and come to an agreement about them with the other riverain governments, in order that deference may be shown to the wishes of the Powers, without infringing on the sovereign rights of the riverain States'. The enforcement of the Navigation Act was contested in the absence of a collective decision, and the Porte yielded and agreed to wait for the observations of the contracting powers before applying the Riverain Commission's Navigation Act. ${ }^{79}$

77 Protocol no. 18 of 16 August 1858, in Sturdza, Recueil de documents, 67-77.

78 Ibid.

79 Ibid. 
With the Riverain Commission contested by the five non-riparian countries, the term of the European Commission had to be prolonged. On 19 August 1858, the seven plenipotentiaries decided to extend it until the completion of the works which had started at Sulina. ${ }^{80}$ This was again a very ambiguous decision, which opened the way for future prolongations.

In the following months, the four sovereign delegates in the Riverain Commission worked in Vienna to modify the Navigation Act. On 1 March 1859, they signed the Additional Articles to the 1857 Act, which included significant changes to the initial agreement. Riparian states could introduce exceptions from the general rule, and thus allow shipping companies of non-riparian countries inland navigation. Freedom of navigation was extended to Danube's tributaries, while other changes referred to the more liberal organisation of navigation and trade. ${ }^{81}$

Austria started to apply the Navigation Act in its waters in $185^{8}$ and tried to convince the other riverain states to do the same. The pro-Austrian provisional government of Moldavia agreed to introduce preliminary measures, but a new cabinet terminated this in April 1859, after the Porte suspended its application in its own territorial waters. ${ }^{82}$ European powers rejected the 1859 Additional Articles, and Austria, defeated in the war against France and Sardinia, had other priorities on its diplomatic agenda. By 1859 the Riverain Commission formally ceased to exist, although the Austrians tried to resurrect it several times in the ensuing decades and used it at other critical junctures to counterbalance the claims of non-riparian states.

The European Commission survived as the only organ that represented the collective will of Europe's Concert of Powers. All seven governments accepted the special status of the Maritime Danube, part of a peripheral region where the Russian authorities could not or would not remove the natural and artificial sources of shipping insecurity. This status was confirmed at the 1856 Paris Peace Congress not only by transferring the Danube Delta from defeated Russia, but also by adding to it a portion of Southern Bessarabia, which broke any territorial connections between Russia and the Danube.

\footnotetext{
8o $\quad$ Protocol no. 19 of 19 August 1858, ibid., 77.

81 Ibid., $78-79$.

82 Focas, The Lower Danube River, 262.
} 
The internationalisation and institutionalisation of Danube navigation through the stipulations of the 1856 Paris Treaty created exceptional juridical instruments that added to previous interpretations of the 1815 Vienna Treaty. The Commission was such an innovation, motivated by the exceptional situation of the region where it would act. The Commission was established as an executive technical institution, an agency for showcasing the Great Powers' direct involvement in turning the Maritime Danube into a safe and reliable transportation infrastructure. As riparian states along the Lower Danube did not have the hydraulic expertise and the financial resources to complete such a task, Europe's support was even more remarkable. The western victors had direct economic interests in the region, but multilateral involvement seemed a fair solution given the crucial importance of establishing a system of security and predictability for commercial exchanges along the most strategic portion of an international river. At the same time, it can be added that the European Commission was one of the several commissions appointed through the 1856 Paris Treaty to enforce some of the most complex decisions of Europe's Great Powers. A 'Special Commission' had to investigate the present state of the Principalities and to propose bases for their future constitutional organisation, while the same states were to send 'delegates' to decide on the course of the new Russian-Ottoman borderline. As part of this framework, the European Commission was one of the means of quickly executing the terms of the treaty.

With the western powers united in their determination to be part of the institutional framework that was to regulate navigation along the Maritime Danube, they secured their voice in a temporary organ, terminable by common consent, whose jurisdiction was limited to the region where shipping insecurity was acute. ${ }^{83}$ The principle of internationalisation as understood by the non-riparian victors was applied only in the Danube Delta area, i.e. in Ottoman territorial waters. The rest of the river followed the jurisdiction of each riparian state, so eventually the Danube ended up being less uniform than before the Crimean War.

The proceedings of the Riverain Commission proved that after Russia's removal from the Danube, Austria acted as the new hydro-hegemon. Its passiveaggressive programme was veiled under a discourse privileging the 'sovereign rights' and 'national interests' of riparian states. But for the western powers the Riverain Commission was, in Viennese hands, just an instrument for further political and economic expansion. The asymmetric power relation along the Danube's valley made Austria the 'usual suspect' for such hegemonic plans

83 Bacon, 'British Policy and the Regulation of European Rivers of International Concern,' British Yearbook of International Law 10 (1929): 168. 
and, in fact, prevented the Riverain Commission from reconvening and resuming works after the failure of its plans in the first years after 1856 .

The Danube remained outside a fully internationalised regime and lacked a central regulating agency for its navigation, but its maritime section received a special status that was served by a similarly exceptional organisation, the Commission. Its resilience in such troubled waters depended on the ingenuity of the delegates based at Galați to instil a security regime in the marshy waters of the Danube Delta. 